\title{
Foresight study blazes trail in Germany
}

[MUNICH] Materials and life scientists in Germany should work more closely together, according to the country's first pilot exercise in technology foresight. It also concludes that there should be more interdisciplinary projects with a wide range of potential applications.

The report of the exercise, published last week, identifies the most promising areas of research with potential applications as molecular architecture, molecular- and bioelectronics, and "materials whose properties are determined by interfaces".

The pilot study was carried out by a group headed by Dagmar Schipanski, an electronics engineer and former president of the Wissenschaftsrat, Germany's science council. The study involved 12 scientists selected by Germany's six major research organizations, including the Deutsche Forschungsgemeinschaft (DFG), the Fraunhofer Society and the Max Planck Society (MPS).

These organizations will now discuss the study's methods and its results. A decision about whether its approach to technology foresight should be expanded to other areas of research - possibly the life sciences - is expected in the next few months.

The study panel, working with German and international scientists including Nobel prizewinners Klaus von Klitzing of the Max Planck Institute for Solid State Physics in Stuttgart and Jean-Marie Lehn of the Louis
Pasteur University in Strasbourg, France, tried to predict areas of materials sciences likely to become particularly significant.

Although no direct funding recommendations are made, the authors specify research topics they consider as mediumterm priorities. These include the synthesis and structural analysis of functional molecules with specified electrical, optical and ionic qualities, and investigations of the organization of very large self-organizing systems, and of protein folding.

The pilot study was set up by the Wissenschaftsrat which, after lengthy discussions, recommended four years ago that independent technology foresight studies of scientific research should be carried out in Germany. Materials science was chosen as the subject because the Wissenschaftsrat had already carried out a preliminary analysis of non-university materials science in Germany in 1995 (see Nature 379, 384; 1996).

One goal was to test suitable methods for technology foresight exercises in other areas of research. The authors agreed on a mix of methods proposed by Hariolf Grupp, vicepresident of the Fraunhofer Institute for Systems and Innovation Research at Karlsruhe, and a member of the study group. Grupp's proposal combined qualitative methods, such as peer review, and quantitative-statistical methods, such as 'bibliometric mapping' of recent international publications, as well as an analysis of a 1993 'Delphi' report on the development of science and technology.

"Many of us were rather sceptical about the use of bibliometric analysis," says Dietrich Haarer, an experimental physicist at the University of Bayreuth who has been given leave to take up the post of head of physics research at Bayer. "But it revealed interesting links; for instance the surprising frequency of cross-referencing between biophysicists and mathematicians, and between organic chemists and semiconductor researchers."

Technology foresight has been introduced in several other countries, but Germany, where scientific freedom is protected by the constitution, has tended to be sceptical. The Wissenschaftsrat had long hesitated to recommend technology foresight, fearing that it could be seen as interfering with the DFG's or MPS's funding principles. Some scientists have been concerned that foresight studies could interfere with their constitutionally guaranteed freedom to research.

But Schipanski, who promoted the strategy during her tenure as president between 1996 and 1997, denies that technology foresight is a step towards centrally directed research. "We do not intend either to replace existing principles, such as the DFG's peerreview system, or to trim basic research," she says. "Technology foresight helps to ensure common ground between scientists, politicians and the public." QuirinSchiermeier

\section{Utah university finally drops out of cold-fusion patent chase}

[воSтоN] A US university has stopped pursuing 'cold-fusion' patents based on the work of the chemists Stanley Pons and Martin Fleischmann. This represents "the end of a chapter" for the University of Utah, which has spent about $\$ 500,000$ in pursuing the technology, according to Richard Koehn, its vice-president for research.

The decision comes nine years after a press conference at which Pons and Fleischmann described a simple technique for producing nuclear fusion at room temperature (see Nature 338, 364; 1989). "After nearly a decade of work on this subject by respectable people, there has been no progress in duplicating the original claims," says Koehn. "For that reason, we decided it was not appropriate to spend any more public funds on this."

The university had been bound by its original agreements with Pons and Fleischmann to fight for patent approval in both the United States and Europe. But such endorsement of the original claims has not been forthcoming. ENECO, the company in Salt Lake City that acquired rights to both the patents and technology, relinquished its

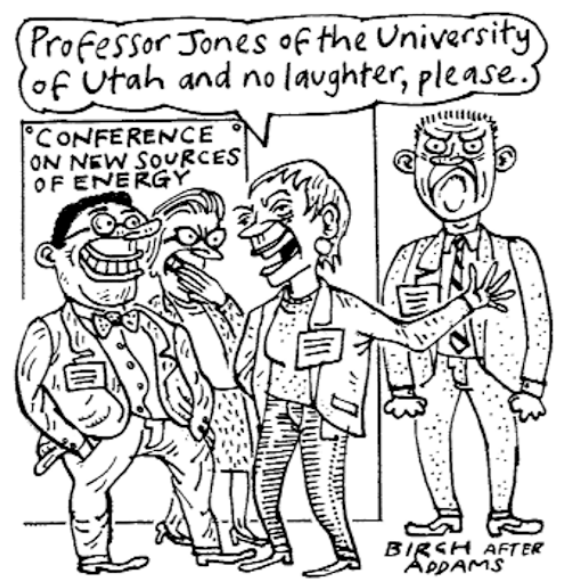

licence last year after a fruitless and expensive attempt to win patent approval.

The university then tried to relicense the patents, but found no takers. Facing the estimated \$1 million-\$2 million in legal fees needed to pursue appeals in support of the patent applications, the university offered the licence to Pons and Fleischmann themselves, who declined. "At that point, we were finally free to step away from this technology," says Koehn.
The episode has dealt a "body blow" to the university's reputation, he says, because of the lack of technical progress in cold fusion and the way the claims were originally publicized.

But cold fusion advocates are not giving up. "The abandonment of a patent has no bearing on the science," Fleischmann said last month. "The research can proceed in a more positive way without a patent claim."

Eugene Mallove, editor-in-chief and publisher of Infinite Energy magazine, admits: "There is very little money in this field, but hundreds of scientists are still conducting experiments. The real action these days is in the commercial sector."

Government backing is scarce: the Japanese-sponsored research programme ended this year (see Nature 389, 10; 1997), and the US Department of Energy stopped funding cold fusion work in 1989.

Hal Fox, editor of the Journal of New Energy, thinks that cold fusion will ultimately be replaced by 'plasma-injected transmutation', a low-energy process that transforms heavy radioactive elements into stable ones.

Steve Nadis 